\title{
REFUGEE CHILDREN UNDER THE MALAYSIAN LEGAL FRAMEWORK
}

\author{
Dina Imam Supaat*
}

\begin{abstract}
This study will delve into the Malaysian legal framework for the protection of refugee children; their legal status under the law; and guarantee to their rights. It will first identify the general protection under various Malaysian statutes relevant to refugee children. Discussion will continue to emphasise on any adverse effect of the legal provisions on refugee children. This will then followed by analysing Malaysia's international commitment and obligation relating to children in general with some reference to refugee children. Discussion will touch on the role and mandate of the United Nation's High Commissioner for Refugee's (UNHCR) office, to protect refugee, Malaysia's commitment as a state party to the United Nation Convention on the Rights of the Child (UNCRC) and it's refusal to ratify the 1951 Convention Relating to the Status of Refugee (CRSR). Other dimension of this paper is the highlight of the adverse effects of inconsistent domestic legal provisions on the enjoyment of rights by refugee children. Finding of this study will show the extent of protection offered to refugee children under domestic laws and the reasons why Malaysia should fulfill its international obligation towards refugee children and further effort that must be initiated to ensure compliance to protection under international law.
\end{abstract}

Keywords: Refugee children, Malaysian law, rights of the child.

\section{Introduction}

In international law, a refugee child or a minor is defined in accordance with the ruling of the United Nations High Commissioner for Refugees (UNHCR), which combines the definition of refugee in the 1951 Convention Relating to the Status of Refugees (CRSR) with the meaning of a child in Article 1 of the United Nations Convention

Senior Lecturer, Faculty of Syariah and Law, Universiti Sains Islam Malaysia 
on the Rights of the Child (CRC). Thus, refugee children are persons who are below the age of 18 years ${ }^{2}$ and who:

....owing to a well founded fear of being persecuted either because of race, religion, nationality, membership of a particular social group, political opinion, are outside the country of nationality or former habitual residence and are unable to or unwilling to avail themselves to the protection of the country of nationality or unable to or unwilling to return to his country of residence, ${ }^{3}$

Nevertheless, in the Malaysian context, the term refugee is not confined to refugees as technically defined in the CRSR only. It includes refugees who left their country of origin due to grounds not listed in the CRSR such as natural disasters and generalised violence. ${ }^{4}$ The Filipinos for instance left their homeland and seek sanctuary in Sabah to escape armed conflicts and civil wars at the Southern Philippines. ${ }^{5}$ Even the Asian-Africa Legal Consultative Organisation (AALCO) to which Malaysia is a member adopted the Bangkok Principles On Status and Treatment of Refugees (Bangkok Principles), a non- binding instrument that defined refugee in a wider sense by recognising every person who is compelled to leave his country of nationality or place of habitual residence and to seek refuge in another place due to external aggression, occupation, foreign domination or events seriously disturbing public order as refugees. ${ }^{6}$

The aim of this study is to identify the extent of protection provided to refugee children under the Malaysian legal framework using library based research method. It begins by examining various acts

\section{CRC, Article 1.}

CRSR, Article 1 A (2).

4 The definition of refugee under the CRSR was criticised for being too narrow and rigid causing many refugees to miss the protection under the CRSR. See Eduardo Arboleda, 'Refugee Definition in Africa and Latin America: The Lessons of Pragmatism' (1991) 3 (2) Int J Refugee Law 185-207; and Elizabeth J. Lentini, 'The Definition of Refugee in International Law: Proposals For the Future' (1985) 5 B.C. Third World L.J. 183- 198.

5 Paridah Abdul Samad and Darulsalam Abu Bakar, 'Malaysia- Philippines Relations The Issue of Sabah' (1992) 32 (6) Asian Survey 554- 567, 563.

6 Bangkok Principles, Article 1 (2). Other regional instrument such as the American Convention on Human Rights 1969 and the African Charter on Human and People's Rights 1981 also adopted wider definition of refugee than the CRSR. 
and explaining the relevant legal provisions. Then it looks at other form of protection for refugee children provided by the UNHCR, an important institution that is mandated to protect people of concern including refugees. Next, the discussion focuses on Malaysia's obligation towards refugee children under the international document, the CRC and the reasons why it continue to reject the CRSR.

This study is a significant effort in making refugee issues a main agenda in the deliberation of law reform in the country. The scarcity of scholarly works on refugees and refugee children in the Malaysian jurisdiction is an evident that more attention and studies are needed to address legal issues surrounding the group. Data collection conducted for this study reveals that most information on the condition and treatment of the current group of refugees come from the reports of UNHCR Malaysia, ${ }^{7}$ NGOs such as the Child Rights Coalition Malaysia, ${ }^{8}$ Amnesty International, ${ }^{9}$ Human Rights Watch, ${ }^{10}$ SUARAM,${ }^{11}$ and refugee community groups. ${ }^{12}$ Previous

7 See for instance articles and news released by the UNHCR and published at $<\mathrm{http}: / /$ www. unhcr.org.my/news_archive.aspx>

8 See Child Rights Coalition Malaysia, Status Report on Children's Rights in Malaysia December 2012 (CRCM 2012) http://www.psthechildren.org.my/media/upload/news/crcmalaysia-report-on-childrens-rights-2012-10.pdf accessed 22 August 2013.

9 For example, Amnesty International, Malaysia: Unlawful Killings, Custodial Deaths, Torture, Exploitation of Migrants and Cotinued Restrictions of Free Expression and Peaceful Assembly (Amnesty International, 2103) http://www.amnesty.org/en/lib/asset/ ASA28/003/2013/en/10af1c11-575f-41f4-a849-e8a8c5f9c987/asa280032012en.pdf accessed 14 May 2014.

10 For example, Human Rights Watch, 'Living in Limbo Burmese Rohingyas in Malaysia' (Report) (Human Rights Watch, August 2000) <http://www.hrw.org/legacy/reports/2000/ malaysia/index.htm>accessed 23 June 2010;

11 FIDH \& SUARAM, 'Undocumented Migrants and Refugees in Malaysia: Raids, Detention and Discrimination' (Report) (International Federation for Human Rights, 19 March 2008) http://www.fidh.org/IMG/pdf/MalaisieCONJ489eng.pdf accessed 15 November 2008.

12 There are several refugee community group that post their reports on the situation their particular ethnic refugee community in Malaysia for instance the refugee from Myanmar. Chin Human Rights Organisation and Myanmar Ethnic Rohingyans Human Rights Organisation Malaysia are two of them. See for instance Chin Human Rights Organisation, 'Seeking a Safe haven: Update on the Situation of the Chin in Malaysia' (Chin Human Rights Organisation, 2006) <http://www.refugees.org/uploadedfiles/CHRO\%200706Seeking_a_ Safe_Haven.pdf $>$ and Myanmar Ethnic Rohingyans Human Rights Organisation Malaysia (MERHROM), 'Rohingya Refugees' Dilemma Remains Unsolved' (MERHROM, 21 June 2007) <http://merhrom.wordpress.com?2007/06/21/rohingya -refugees'-dilemma remains- unsolved. 
studies such as by Sutter, ${ }^{13}$ Wain, ${ }^{14}$ and Robinson ${ }^{15}$ concentrate on the plight of the Indochinese diaspora who fled to safe countries including Malaysia with brief discussion of the international law perspective on the issue. Muntarbhorn ${ }^{16}$ only address the treatment of refugees by the Malaysian authorities with no attention to refugee children. Works by Rachagan ${ }^{17}$ and Kassim ${ }^{18}$ give some insights on Filipino refugees but not the legal aspect of the matter. Meanwhile Davies ${ }^{19}$ made a more comprehensive study to expound the reason why Asian countries including Malaysia refuse to ratify the 1951 Convention Relating to the Status of Refugee. The recent work by Idris $^{20}$ looks at refugee issue from social and political perspective. All of these literatures pointed out the fact that Malaysia does not have specific law to regulate refugees and hence, the refugees are not protected. This is where this study becomes relevant and timely as it attempts to fill the gap by discussing the extent of protection for refugee children provided under the Malaysian legal framework.

Refugee children become the subject of this study for three reasons. Firstly, because they are more vulnerable than adult refugees and ordinary citizen children. ${ }^{21}$ Their positions as children and refugee make them more susceptible to various risks and danger such

13 Valerie O'Connor Sutter, The Indochinese Refugee Dilemma (Louisiana State University Press, London 1989)

14 Barry Wain, The Refused: The Agony of the Indochinese Refugees (Simon and Schuster, New York, 1982)

15 W C Robinson, Terms of Refuge: The Indochinese Exodus and The International Response (Zed Books Limited, London, 2000)

16 Vitit Muntarbohrn, The Status Of Refugees In Asia (Clarendon Press, London 1992).

17 Sothi Rachagan, 'Refugees and Illegal Immigrants: The Malaysian Experience with the Filipino and Vietnamese Refugees' in Rogge J R (ed) Refugees: A Third World Dilemma ( Rowman \& Littlefield, 1987)

18 Azizah Kassim, 'Filipino Refugees in Sabah: State Responses, Public Stereotypes and the Dilemma Over Their Future' (2009) 47 Southeast Asian Studies 52, 65

19 Sara E Davies, Legitimising Rejection: International Refugee Law in Southeast Asia (Martinuss Nijhoff Publisher, Leiden 2008)

20 Arzura Idris, Malaysia and Forced Migration (2012) 20 (1) Intellectual Discourse 31-54.

21 UNHCR, Refugee Children: Guidelines on Protection and Care (1994) <http://www. refworld.org/docid/3ae6b3470.html> accessed 19 June 2014. 
as being abuse and treated as illegal immigrants or criminals. ${ }^{22}$ Secondly, because they are naive, dependent and unable to fend for themselves which make them in need of continuous support from adults in dealing with affairs affecting them and in the exercise of their rights. ${ }^{23}$ Thirdly, refugee children form the majority percentage within worldwide refugee population and in Malaysia the current number is more than 20 percent. ${ }^{24}$ There is an increasing concern on their survival, future, and their entitlement as children such as the right to education. ${ }^{25}$

\section{General Overview}

Refugee children ${ }^{26}$ continue to find themselves in complicated situation in Malaysia even though the country has vast experience in hosting a large number of refugees for decades. From 1970s until today, refugee children from various countries in the Southeast Asian region and beyond have crossed international borders with their families or on their own to escape various forms of persecution,

22 See Nigel Thomas and John Devaney, "Safeguarding Refugee and Asylum- seeking Children" (2011) 20 Child Abuse Review 307- 310, 307; and Alice Farmer, "Refugee Responses, State-like Behavior, and Accountability for Human Rights Violations: A Case Study of Sexual Violence in Guinea's Refugee Camps" (2006) 9 Yale H.R. \& Dev. L. J. 44-103. It discusses the vulnerability of refugee women and girls to sexual violence and exploitation in refugee camps and the lack of access to justice; and Wendy A. Young, 'The Protection of Refugee Women and Children Litmus Test for International Regime Success' (2002) 3 Geo. J. Int'l Aff. 37- 44 that discuss lack of protection and security needed by refugee children and women.

23 UNHCR, Refugee Children: Guidelines on Protection and Care (1994) $<$ http://www. refworld.org/docid/3ae6b3470.html> accessed 19 June 2014.

24 UNHCR Malaysia, Figures at a Glance (UNHCR Malaysia, 2014) <http://www.unher. org.my/About_Us-@Figures_At_A_Glance.aspx > accessed 30 June 2014.

25 The preamble to the United Nations Cenvention on the Rights of the Child 1989 acknowledges that children should enjoy their rights, be given assistance, protection and care; treated without discrimination and brought up in family environment in order to main their dignity and fully develop. Also see Bhabha, J., 'Independent Children, Inconsistent Adults: International Child Migration and the Legal Framework'. (2008) Innocenti Discussion Paper No. 08/3. UNICEF, explain how children are neglected in the protection system; and Smythe,J. A., "I Came to United States and All I Got Was This Orange Jumpsuit" Age Determination Authority of Unaccompanied Alien Children and the Demand for Legislative Reform" (2004) Child. Legal Rts. J. 28 analyse problems that occurs when the authority have doubt over a child's age.

26 The term 'forced migrant' and 'internationally displaced people' are also used to refer to refugee. 
wars, generalised violence, severe human rights violations, political conflict, civil strife, and natural disasters in their country of origin to seek refuge in Malaysia. ${ }^{27}$ These include the Indochinese and the Cambodians (1970s to 1990s) ${ }^{28}$ and the Filipinos from the Southern Philippines (1975 until today). ${ }^{29}$ Refugee children from Indonesia, Myanmar, Nepal, Sri Lanka, Somalia, Iraq and Afghanistan are also currently seeking sanctuary in the country. ${ }^{30}$

Today, the number of refugee children in Malaysia stood at more than 30,000 people. This constitutes more than $30 \%$ of the approximately 146,000 refugees and asylum seekers registered with the UNHCR in Malaysia. ${ }^{31}$ These internationally displaced children form part of the alien or migrant community in this country but what has distinguished them from the rest of the migrant population ${ }^{32}$ is that they were forced to migrate and involuntarily leave home for a foreign state in search of a safe haven because their own countries or governments have failed or refused to provide protection. ${ }^{33}$

The presence of refugee children and their community in Malaysia give rise to protection issues for the group and security issues of

27 Vitit Muntarbohrn, The Status Of Refugees In Asia (Clarendon Press, London 1992) 113120.

28 Valerie O'Connor Sutter, The Indochinese Refugee Dilemma (Louisiana State University Press, London 1989) 50

29 Sothi Rachagan, 'Refugees and Illegal Immigrants: The Malaysian Experience with the Filipino and Vietnamese Refugees' in Rogge J R (ed) Refugees: A Third World Dilemma ( Rowman \& Littlefield, 1987) p. 257; and Vitit Muntarbohrn, The Status Of Refugees In Asia (Clarendon Press, London 1992) 113- 120.

30 UNHCR Malaysia, Figures at a Glance (UNHCR Malaysia, 2014) <http://www.unhcr. org.my/About_Us-@Figures_At_A_Glance.aspx > accessed 30 June 2014.

31 UNHCR Malaysia, Figures at a Glance (UNHCR Malaysia, 2014) <http://www.unhcr. org.my/About_Us-@Figures_At_A_Glance.aspx > accessed 30 June 2014. The majority of them are from Myanmar.

32 Migrant population in Malaysia includes a huge number of economic migrants who voluntarily left their home country in search of better economic opportunities and social life and they could be legally and illegally present in Malaysia. The authorities often group refugees as economic migrants. See The Malaysian Bar, Allowing Refugees and Asylum Seekers Access to lawful Employment is a Positive Step in the Right Direction (The Malaysian Bar, 2013) http://www.malaysianbar.org.my/press_statement/press_ release_allowing_refugees_and_asylum_seekers_access_to_lawful_employment_is_a positive_step_in_the_right_direction.html accessed 30 September 2013.

33 Goodwin-Gill, G S, and McAdam, J, The Refugee in International Law ( $3^{\text {rd }}$ Edition, Oxford University Press, Oxford, 2007) 9-12. 
Malaysia as a host country. Since the last four decades refugees have caused agitation to the authority and the society with security and social issues. ${ }^{34}$ Even though there is a basis for refugee children to claim protection under international law, it is difficult to enable the application of international law in local courts. ${ }^{35}$ Moreover, the Malaysian legal framework does not expressly provide protection for children who are being persecuted. ${ }^{36}$ And now, the legal status of refugee children remains unresolved but not sufficiently addressed. In Malaysia, as will be shown in this study, the treatment accorded to refugees is primarily influenced by the non- existence of specific legal provisions regulating internationally displaced children either in a statute regulating aliens in general, or in an exclusive statute. Other factors include the practice of the authority who made no distinction between refugees and illegal immigrants; and reliance on the discretionary power of the authority who devised refugee policies outside the framework of human rights. ${ }^{37}$

\section{General Legal Provisions Relevant to Refugee Protection}

This part examines legal provisions in the acts of Parliament that can offer direct and indirect protection to refugee children even though for many provisions, there is no judicial authority to support

34 See for example HHS KHY HA, 'UNHCR Asked to Verify Status First Before Issuing Refugee Cards' Bernama (Malaysia, 19 February 2009); NMR HK MIS, 'Police Detain Myanmar Refugee Found With Fake Identity Card' BERNAMA (Malaysia, 3 May 2009); and n.a, 'Beggars using refugee Status to Draw Sympathy' New Straits Times (Malaysia, 19 July 2003).

35 It has been argued for example in Amer Hamzah Arshad, 'The Protection of Refugee Children in Malaysia: Wishful Thinking or Reality' (2004) INSAF XXXIII No. 4, p. 105 125 that in states which do not ratify the CRSR, refugee can claim protection under the non-refoulement rule, the rule against return which has become a customary international law. However, studies show that the court is not prepared to recognise the existence of customary rule and its application in domestic courts as decided in the case of $P P v$ Narogne Sookpavit [1987] 2 MLJ 100.

36 Displaced people and forced migrants of the Southeast Asia is a testament that the states of origin have in a way or another failed to provide protection for its own people. See Riwanto Tirto Sudarmo, 'Critical Issues in Forced Migration Studies and the Refugee Crisis in Southeast Asia (2007) UNEAC Asia Papers (Special Issue Refugees and Refugee Policies in the Asia Pacific Region) 13, $23<\mathrm{http}$ ://www.une.edu.au/asiacentre/ PDF/No14.pdf $>$ accessed 4 October 2010.

37 See Amarjit Kaur, 'Refugees and Refugee Policy in Malaysia' (2007) UNEAC Asia Papers (Special Issue Refugees and Refugee Policies in the Asia Pacific Region) 77, 79 $<$ http://www.une.edu.au/asiacentre/PDF/No18.pdf $>$ accessed 16 August 2009. 
the application of the provisions. Discussion in this section will demonstrate the absence of term refugee in the domestic framework and that the protection effect of many of the provisions are not yet tested in court

\section{The Federal Constitution}

As with many other countries, the Malaysian Federal Constitution visibly pledged the fundamental liberties of individuals. The guarantees of such rights are made under Article 5- 13 encompassing among others, liberty of the person (Article 5); prohibition of slavery and forced labour (Article 6); equality before the law (Article 8); and rights in respect to education (Article 12). These rights also extend to children as they are to adults. The fact that the word refugee does not exist in the basic legal instrument of the country does not seize refugees from the protection of the constitution. Where the word 'person' is used in the Federal Constitution, it should include citizens and noncitizens. ${ }^{38}$ Provisions on fundamental liberties for example, are using the word 'person' in making the guarantee of the enjoyment of basic rights for everyone. Aggrieved individuals may seek a declaration that the government's conduct is invalid or unconstitutional if certain act is contrary to the provision of the constitution. ${ }^{39}$ Legal presence in the country is not a prerequisite to commence an application to the court for such declaration. ${ }^{40}$ However, non-citizens including children, are exempted from enjoying the rights and privileges under Article 9, 10 and 12 which are provided for Malaysian citizens exclusively. ${ }^{41}$

38 Harding, A., Law, Government and the Constitution in Malaysia (Lexis Nexis, Kuala Lumpur 1996) 209.

39 For instance when a person is detained unlawfully or without being informed of the reason and ground of detention contrary to Article 5 (2) and (3). See Aminah v Superintendant of Prison, Pengkalan Chepa, Kelantan (1968) 1 MLJ 92; and N Indra a/p Nallathamby (administratrix of the estate and dependant of Kugan a/l Ananthan, deceased) $v$ Datuk Seri Khalid bin Abu Bakar \& Ors [2014] 8 MLJ 625.

40 In the case of Alfredo bin Pakkal (Filipino Illegal Immigrant) $v$ Deputy Minister of Home Affairs Malaysia \& Ors (2011) MLJU 334 and Sukma Darmawan Sasmitaat Madja $v$ Ketua Pengarah Penjara Malaysia \& Anor [1999] 1 MLJ 266, their status as noncitizens do not stop them from making the application to the court and for Alfredo, his status as an illegal migrant does not make him ineligible to bring his case to the court.

41 Harding, A., Law, Government and the Constitution in Malaysia (Lexis Nexis, Kuala Lumpur 1996) 224. 


\section{Equality}

In relation to refugee, Article $8^{42}$ on equality is of particular interest as it may be used to depict the applicability of legal protection for citizens on the refugees as well. The relevant provision: 'all persons are equal before the law and entitled to the equal protection of the law' leads to the comprehension that refugees should be treated equally like the citizens. Unfortunately, this provision is actually restricted by clause (2) that declares that only citizens are protected from discriminatory legislations which discriminate people on the ground of religion, race, descent or place of birth. ${ }^{43}$ Hence, laws which discriminate non-citizens are valid laws and can take effect. However, legislations not relating to the subject matters in Article 8 should not be discriminatory to everyone; citizens and noncitizens on any ground. Thus, refugee related legislations such as child protection, immigration and education should apply equally to citizens and non- citizens. Equality in Article 8 does not mean that each and every citizen shall be treated equally. ${ }^{44}$ It requires that similar case should be treated alike. ${ }^{45}$ To benefit from the protection of Article 8, refugees must show that the discrimination is not allowed under the constitution and it had caused them damage. In Ahmad Tajuddin bin Ishak v Suruhanjaya Pelabuhan Pulau Pinang[1997] 1 MLJ 241 it was decided that discriminatory per se is not actionable. The plaintiff must prove that the alleged discrimination was both unfair and resulted in harm or injury. The restriction of Article 8 (2) and the acceptance of discrimination practice by the courts however, will not deny the fact that refugees are still entitle to claim equal law protection of their rights.

42 The Federal Constitution, Article 8 :

(1) All persons are equal before the law and entitled to the equal protection of the law.

(2) Except as expressly authorized by this Constitution, there shall be no discrimination against citizens on the ground only of religion, race, descent or place of birth in any law relating to the acquisition, holding or disposition of property or the establishing or carrying on of any trade, business, profession, vocation or employment.

(3) There shall be no discrimination in favour of any person on the ground that he is a subject of the Ruler of the State.

(4) No public authority shall discriminate against any person on the ground that he is resident or carrying on business in any part of the Federation outside the jurisdiction of the authority.

43 The Federal Constitution, Article 8 (2); and Harding, A., Law, Government and the Constitution in Malaysia (Lexis Nexis, Kuala Lumpur 1996) 236.

44 Datuk Harun Idris v Public Prosecutor [1977] 2 MLJ 155

45 Harding, A., Law, Government and the Constitution in Malaysia (Lexis Nexis, Kuala Lumpur 1996) 237. 


\section{Immigration Act 1959}

Immigration law in the country is fundamentally based on Malaysian Immigration Act 1959, Passport Act 1966 and regulations made under these Acts. None of these acts mention refugee in its provisions or provide any procedure relating to refugee status. Provisions of the Immigration Act apply to every regular person entering Malaysia and refugees alike without exception. The Act is not a tool to protect refugee, instead, it is a device utilised to combat illegal entry and stay $^{46}$ regardless of the persons' claim as victims of persecution.

\section{Main Provisions Affecting Refugees}

The Act governs all entries; by land, sea and air into Malaysia and the requirement of valid permit and travel document for the entry and stay. Persons entering Malaysia without valid permit or pass are considered 'illegal immigrant' i.e. persons other than citizen who contravene the provisions of section $5,6,8,9$, or 15 of the Immigration Act 1959; and provisions of regulation 39 of the Immigration Regulations 1963. ${ }^{47}$

Section 5 of the Act made it an offence for any person to enter Malaysia through non prescribed or unauthorized point of entry. In refugee situation, many of them travel without legal document and leave their country of origin and enter another country clandestinely using unauthorized point of entry to evade the authority. Under section 6, entry without valid permit or pass is an offence. A number of refugees have been charged for offences under this section. ${ }^{48}$ While the court is unable to spare them from jail sentence as they are bound to enforce the Immigration Act, the refugees manage to escape whipping because their status as refugee under the UNHCR mandate are being used as a mitigating factor.

Section 8 defines prohibited migrants: persons who are not permitted to enter or, and remain in Malaysia for reasons specified under the subsections 1-6. If a refugee falls into any of the category of

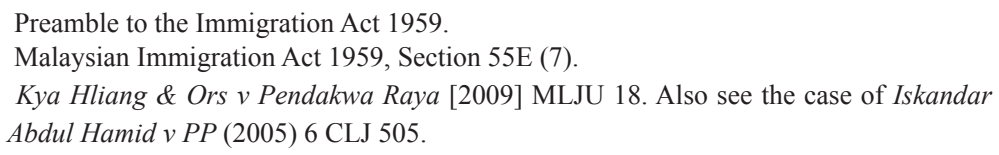


prohibited migrant, ${ }^{49}$ he or she may be denied entry. This is a situation where asylum seekers attempt to enter the country through valid channel and possess valid travel document. Regular immigration check conducted upon arrival at point of entry may found that these asylum seekers can be classified as 'prohibited migrant' when they are unable to show that they have means to support themselves or will likely become a charge on the public. ${ }^{50}$ This is a quite a common cause for refusal of entry in many jurisdiction. In Malaysia, it does not make any difference if a person presents himself to the immigration and declares that he wants to apply for asylum because there is no regulation or mechanism to deal with asylum application at the border. Regardless of a person's claim about his persecution in his country of origin, he will be treated similarly like any other prohibited migrant. ${ }^{51}$ Persons denied entry will be deported and if deportation is not possible at that time, they will be detained until deportation can be arranged for them. However, there are many cases where children cannot be deported but let to stay and roam the street. ${ }^{52}$

Conviction under section 5, 6, 8 or 9 of the Immigration Act will make a person liable to a removal from Malaysia ${ }^{53}$ and while waiting for the removal, a person may be detained in custody. ${ }^{54}$ Regrettably,

49 For example under the Immigration Act 1959, section 8 (3) (a) any person who is unable to show that he has the means of supporting himself and his dependants (if any) or that he has definite employment awaiting him, or who is likely to become a pauper or a charge on the public; $(m)$ any person who, being required by any written law for the time being in force to be in possession of valid travel documents, is not in possession of those documents or is in possession of forged or altered travel documents or travel documents which do not fully comply with any such written law; $\mathrm{d}(f)$ any person who procures or attempts to bring into Malaysia prostitutes or women or girls for the purpose of prostitution or other immoral purpose.

50 Immigration Act 1959, Section 8 (3) (a)

51 Alice Nah, "Refugee and Space in Urban Areas in Malaysia" (2010) 33 FMR 29- 29; Alica Nah and Tim Bunnel, "Ripples of Hope: Acehnese Refugees in Post- Tsunami Malaysia (2005) 26 (2) Singapore Journal of Tropical Geography 249- 256.

52 This lead to other social problems. See T S Bahrin, and S Rachagan, 'The status of Displaced Filipinos in Sabah: Some policy Considerations and Their Long Term Implications' in Lim Joo-Jock Vani, S, Armed Separatism in Southeast Asia (Institute of Southeast Asian Studies, Singapore 1984)190, 192; and Camilla Olson. 13 ${ }^{\text {th }}$ of June 2007. "Malaysia: Undocumented Children in Sabah Vulnerable to Statelessness". Refugees International. www.refugeesinternational.org (Accessed 3 July 2012).

53 Ibid. Section 32, 33

$54 \quad$ Ibid. Section 34 
contrary to the general principle of criminal law in proving one's guilt, the onus of proof that a person does not contravene the provisions of section 6 and 8 lies on that person not the prosecution..$^{55}$ Under the Malaysian Immigration Act 1959, all refugees and other types of illegal migrants are not distinguished between each other. Without valid documentation to remain and stay in Malaysia, illegal immigrants including refugees are subject to detention, deportation and whipping. ${ }^{56}$

Despite the controversial provisions of the Immigration Act, many believe that some provision of the act can be utilised to rectify the refugee protection problem to a certain extent. It has been suggested that in the light of providing initial protection for refugees, they should be exempted from the incriminating provisions of the Act which are contrary to the basic rights of refugees or asylum seekers. ${ }^{57}$ Director General can exercise his power under section 55 for the benefit of asylum seekers and refugees since he has the discretionary power to exempt a person or a group of persons from any or all provisions of the Act. ${ }^{58}$ The exemption of asylum seekers and refugees from section 5, 6 and 8 will make them impervious against criminal charge for entry at unauthorized point, and entry without valid permit/ pass/ travel document.

\section{Laws on Child Protection and Child's Rights}

Malaysian legal framework on the protection of children from abuse, violence, labour exploitation, protection of rights and juvenile justice lies in a number of statutes ${ }^{59}$ but each statute is far from providing enough safeguard for the protection of the rights of the child as guaranteed under the UNCRC. Discussion in this section is

\footnotetext{
$55 \quad$ Section 6 (4) and 8 (4) of Act 155

56 Malaysian Immigration Act 1959, Section 57

57 Arshad, A H, "The Protection of Refugee Children in Malaysia: Wishful Thinking or Reality" (2004) INSAF (34: 4) 105

58 Section 55 of Malaysian Immigration Act 1959/ 1963.

(1) Notwithstanding anything contained in this Act, the Minister may by order exempt any person or class of persons, either absolutely or conditionally, from all or any of the provisions of this Act and may in any such order provide for any presumptions necessary in order to give effect thereto.

(2) Every order made under this section which relates to a class of persons shall be published in the Gazette.

59 These includes the Child Act 2001, Children and Young Persons (Employment) Act 1966, and the Education Act 1996.
} 
limited to the Child Act 2001 and the Education Act 1996 and it will show the constraint of Malaysian law in providing protection for children and refugee children as opposed to the rights warranted by the international law.

\section{Child Act 2001}

The Child Act 2001 (Act 611) is a milestone of child protection regime in Malaysia. Its enactment was borne out of Malaysia's obligation as a state party to the UNCRC from 1995 and the provisions are formulated based on the four core principles of the UNCRC: non discrimination, best interest of the child, the right to life, survival and development and respect for the views of the child. ${ }^{60} \mathrm{~A}$ child is defined under the Act as a person under the age of eighteen years; and in relation to criminal proceedings, means a person who has attained the age of criminal responsibility as prescribed in section 82 of the Penal Code [Act 574] ${ }^{61}$ Children who are victims of abuse and children offenders are now dealt with under a single piece of legislation. Its Preamble provides that every child is entitled to protection and assistance in all circumstances without discrimination for the reason of race, colour, sex, language, religion, social origin or physical, mental or emotional disabilities or any status. ${ }^{62}$ Thus, even though the Act does not specifically declares that the Child Act 2001 shall apply to all children equally without any discrimination whatsoever, the preamble should be used as the basis to extend similar scope and standard of protection to each child in Malaysian jurisdiction. Take for example the assertion made by the Minister of Women, Family and Community Development who stressed that every child is entitled to protection and assistance in all circumstances without regard to distinction of any kind, such as race, colour, sex, language, religion, social origin or physical, mental or emotional disabilities or any other status. ${ }^{63}$ This means that the status of a child as illegal immigrant as the authority put it, should not deny him or her of the protection under the Child Act 2001.

\footnotetext{
60 See Ministry of Women, Family and Community Development, 'Implementation of the Convention on the Rights of the Child Malaysia's First Report' (2006) p. 37\&

61 Child Act 2001, Section 2,

62 Child Act 2001

63 News Straits Times, April 182011
} 
Under this Act, a child is said to be in need of care and protection includes among others: a child who has been or is subjected to substantial risk to be physically or emotionally injured or sexually abused; a child who has been neglected or abandoned by his guardians or parents; and a child who has no parents or guardian, who needs to be examined, investigated or treated for the purpose of restoring or preserving his health and his parents or guardian neglects or refuse to have him examined, investigated or treated. ${ }^{64}$ Again, refugee children are not expressly mentioned or covered under this Act unless he or she falls into any of the category of children in need of protection. The limited situations described in the Act are not enough for refugee children because their situation may not fall under any of the stated conditions. It is doubtful that 'a child who entered the country illegally or without a valid travel document' can simply fit into the description of section 17 unless he is found to be on street or any place begging and receiving donations or carrying out illegal activities which are detrimental to his or her health. ${ }^{65}$

It must be noted that the Child Act is meant to protect children in circumstances which are highly abusive. It was not designed to cater for children lacking legal status or whose fundamental rights as children are being violated such as children denied primary education or healthcare. If the Act is said to have been guided by the guiding principles of the UNCRC, it may be concluded that the guidance is only applicable to a limited section of a child's life and rights. The Act does not in the first place declare the rights that every child should enjoy for being a child and the repercussion that arise when children are unable to exercise their rights.

\section{Education Act 1996}

Primary education is compulsory ${ }^{66}$ in Malaysia, available to all but it is not free prior to 2012. It was a policy that students are still required to pay a minimal fee upon enrolment in primary and

\footnotetext{
64 Child Act 2001, Section 17

65 Child Act 2001, Section 17 (k)

66 Section 29A of the Education Act 1996 provides that the Minister may prescribe primary education to be compulsory education by publishing such order in the Gazzette.
} 
secondary schoo ${ }^{67}$ before the government declared to scrap the fee making primary and secondary education free only for citizens. ${ }^{68}$ Even though the Act does not expressly discriminate children on the ground of their citizenship status and therefore, immigrant children could be enrolled in any public funded school, however, there are some regulations that limit the enrolment of refugees. First, it is a requirement for a child to be registered using his/ her birth certificate. Secondly, primary and secondary education are free for citizens but schools are allowed to charge student a fee for various purposes. These two practices have impeded refugee children's access to public school. In many cases refugee children may not have their birth certificate and thus are not able to register. If they do register, their parents are not capable to fund the payment charged by the school. Furthermore, other related expenses such as for school uniform, books and transportation are also significant obstacles.

\section{Malaysia and International Institution and Law}

This section is intended to discuss Malaysia's obligation under international law. It serves to explain four main areas: Malaysia's relation to the organ of the United Nations, which is the UNHCR; it's refusal to ratify the CRSR, the main refugee protection document in international arena; the obligation of a state party to the CRC pertaining to refugee children; and the role of customary international law in protecting refugees. Discussion in this section will show that there is a big gap between what Malaysia provides for the protection of refugee children and its real obligation from international law perspective; that Malaysia owes a duty towards refugee children under the customary rules; and that certain amount of small step can lead to big change for refugee children.

${ }^{67}$ Previously, parents are burdened with hefty fee but the Ministry issued a guideline which requires school to impose only minimal fee. Thus, parents have to pay RM24.50 (about £5) for primary school and RM33.50 ( about £6.50) for secondary school. See n.a. "Yuran Sekolah tahun depan di Mansuhkan" Utusan Malaysia. 8/10/2011. Available at $<$ http://www.utusan.com.my/utusan/info.asp?y=2011\&dt=1008\&sec=Muka_Hadapan \&pg=mh_03.htm $>$ Accessed 11 January 2012. Nevertheless, financial assistance is available for poor families. Beginning from 2010 all school children are granted RM100 assisstance.

68 See n.a. "Yuran Sekolah tahun depan di Mansuhkan" Utusan Malaysia. 8/10/2011. 


\section{United Nations High Commissioner for Refugees (UNHCR)}

External to the national legal framework is the office of the UNHCR that operates to provide international protection for refugees in Malaysia. The UNHCR has been present in Malaysia since the boat people era in 1970s. As Malaysia is not a party to the refugee convention, UNHCR plays a fundamental and crucial role of providing a broad spectrum of refugee protection, from refugee status determination to finding durable solutions. ${ }^{69}$ By the request of the Malaysian government, UNHCR took the responsibility to register refugees in Malaysia and to determine the individual's refugee status. Those who are recognised as refugees are given identification card/ papers and become persons of concern to UNHCR. ${ }^{70}$ The Malaysian authorities have agreed that those who hold the UNHCR identification papers will not be charged with illegal entry or failure to produce valid travel documents but this is not a guarantee against possible detention and abuse by the enforcement authorities and the civilians voluntary army. ${ }^{71}$ In many reported cases, ${ }^{72}$ refusal to acknowledge UNHCR's mandate has caused refugees and asylum seekers with UNHCR papers to be arrested during raids and road blocks despite showing the identification document to the authorities. ${ }^{73}$ The UNHCR operation is not without issue. First, because there is no specific regime for refugee protection under the Malaysian legal framework, UNHCR is basically operating on the courtesy of the government without legal ground. Without real legal

UHNCR, 'UNHCR in Malaysia' at http://www.unher.org.my/cms/basic-facts/unher-inmalaysia, accessed on 20 May 2009. See UNHCR, Country Operations Plan for 2007 Malaysia, available at http://www.unhcr.org/cgi-bin/texis/vtx/search?page =search\&doc id $=45221 \mathrm{ff} 62 \&$ query $=$ countryoperationsplanmalaysia

70 UNHCR Malaysia, 'Protection' (UNHCR Malaysia) < http://www.unhcr.org.my/What We_Do-@-Protection.aspx> accessed 5 September 2013

71 Beginning 2000, the civilian voluntary army (RELA) was authorized to stop and detain illegal immigrants and this was recklessly and blatantly enforced with serious cases of human rights violation. See reports on such incidents in Human Rights Watch, 'Aceh Under Martial Law: Problems Faced by Acehnese Refugees in Malaysia' (2004) Human Rights Watch Vol. 16. No. 5 (C) p. 12

72 Human Rights Watch, 'Aceh Under Martial Law: Problems Faced by Acehnese Refugees in Malaysia' (2004) Human Rights Watch Vol. 16. No. 5 (C) p. 8

73 US Committee for Refugees, The least risky solution: Malaysia's detention and deportation of Acehnese asylum seekers (US Committee for Refugees, Washington 1998); and Chin Human Rights Organisation, Seeking a Safe haven: Living in Insecurity: Malaysia $<$ http:// www.refugees.org/uploadedfiles/CHRO\%200706Seeking_a_Safe_Haven.pdf >accessed 13 January 2009 p. 4 
power, UNHCR work is less effective as compared to its work in contracting states. ${ }^{74}$ UNHCR's choice in finding durable solution for refugees is confined to finding a resettlement place at a third country and to arrange for voluntary repatriation. Hence, at times the UNHCR is prevented from finding a solution which is in the best interests of the refugee children. Second, the government refused to be involved in any UNHCR's activities but expected the UNHCR to work on the government's term for example it refuse to accept the ground of persecution as recognised under the refugee convention and the mandate of the UNHCR. As a result, it has accused the organisation of blatant recognition of refugees asserting that asylum seekers without genuine and valid claim are simply accepted as refugees and issued with the UNHCR identity cards. ${ }^{75}$ Third, UNHCR presence is only found in Kuala Lumpur. This means refugees must travel to the city to make application. This give rise to expenses and security issues as refugees will always want to avoid the authorities.

\section{The 1951 Convention Relating to the Status of Refugees (CRSR) Malaysia's Rejection.}

The CRSR provides refugees with various rights including protection against return, right to education and rights to gainful employment but it can only benefit refugees who are contracting states to the instrument. Malaysia has been ignoring calls to ratify the CRSR and continues to claim that even without the official duties under the CRSR, Malaysia is still protecting refugees on humanitarian ground. ${ }^{76}$ Malaysia's experience of refugee hosting can be dictated into two major events. The first is the mass influx of refugees during the Indochinese upheaval ${ }^{77}$ beginning from the 1970 s until end of

$74 \quad$ Michael Alexander, 'Refugee Status Determination Conducted by UNHCR' (1999) 112 2) IJRL 251 discusses the problem of UNHCR functioning in Malaysia.

75 Bernama, 'Najib: For Malaysia to decide and Not UNHCR' Daily Express (Sabah, 4 March 2005) $<$ http://www.dailyexpress.com.my/news.cfm?NewsID=33021> accessed 3 November 2010, the then Deputy Prime Minister stressed that UNHCR documentation will not stop the authorities from taking action against illegal immigrants.

76 See Hussein Onn, 'Policy Towards Illegal Migrants' (1979) 2 Foreign Affairs Malaysia 216- 9; _, 'Malaysia Helps "Refugees” on Humanitarian Grounds' New Straits Times (Kuala Lumpur, 2 July 2007) 7

77 Graeme Hugo, 'Postwar Refugee Migration in Southeast Asia: Patterns, Problems and Policy' in John R. Rogge (Ed), Refugee A Third World Dilemma (Rowman\& Littlefield Publisher, USA 1987) 242, 246 
1990s and the fear of residual problem related to it. ${ }^{78}$ Secondly is the inundated flow of Filipino refugees in Borneo and the tensions that built up at some stage between state government of Sabah and the federal government in dealing with the Filipinos. ${ }^{79}$ Both prolonged refugee episodes were met with various unconstructive reactions from the local people. ${ }^{80}$ These corollaries are purportedly being used by the authority to justify the resistance against any call for Malaysia to ratify the 1951 Convention Relating to the Status of Refugee and its 1967 Protocol. ${ }^{81}$ Diverse grounds are being employed by the government to substantiate Malaysia's refusal to recognise refugee or to codify national laws on refugees. Firstly, to Malaysians, the recognition of refugee will be perceived as meddling with domestic tribulation of its neighbouring countries. ${ }^{82}$ Next, Malaysia views the Convention as 'Eurocentric'; has no regards for developing countries and their particular experience in the region; contrary to

78 Astri Suhrke, 'Indochinese Refugees: The Law and Politics of First Asylum'(1983) ANNALS AAPSS 102- 115, 102.

79 Filipino refugee issue is a prolong problem still grappling both the state of Sabah and the Federal Government. See Joseph Pairin Kitingan, 'Speech of Datuk Seri Panglima Joseph Pairin Kitingan, President of Parti Bersatu Sabah (PBS) (22nd PBS Congres, 11 November 2007) in Hongkod Koisaan Penampang, Sabah http://www.pbs-sabah.org/ pbs3/html/Congress2007/ucapan_dasar_2007.html accessed 26 May 2009.

${ }^{80}$ Local people living in the east coast where the boat people landed and stayed in refugee camps showed considerable resentment towards refugees. See Graeme Hugo, 'Postwar Refugee Migration in Southeast Asia: Patterns, Problems and Policy' in John R. Rogge (Ed), Refugee A Third World Dilemma (Rowman\& Littlefield Publisher, USA 1987) 246.

81 In addition to that, the government has also neglected the recommendation of the National Human Rights Commission (SUHAKAM) to ratify principal human rights treaties; the 1966 International Covenant on Civil and Political Rights (ICCPR), 1984 Convention Against Torture and Other Cruel, Inhuman and Degrading Treatment and Punishment (CAT) and 1966 International Covenant on Economic, Social and Cultural Rights (ICESR) and the two optional protocols to the Convention on the Rights of a Child (CRC). See SUHAKAM, 2005 Annual Report (SUHAKAM, Kuala Lumpur 2006) 110. In fact the government has been non- responsive to SUHAKAM's recommendation. See SUHAKAM, 'Report To The $14^{\text {th }}$ Annual Meeting Of The Asia Pacific Forum Of National Human Rights Institutions’ (Amman, Jordan, 3-6 August 2009) 8.

82 Minister in the Prime Minister's Department, Datuk Seri Dr. Rais Yatim remarked when responding to UNHCR's call for Malaysia to accept and admit asylum seekers and refugees by adopting a national legal framework. He even asserted that it is not Malaysia's duty to figure out the persecution faced by refugees in their country of origin. See _ 'Rais: We Have No Intention to Codify Laws on Refugees, Asylum Seekers' New Straits Times (Kuala Lumpur, 25 October 2003) 3. 
Asian values; and entails a huge financial implication. ${ }^{83}$ In addition to that Malaysia is also concern that ratification of the CRSR will be taken by the public as an indication that Malaysia is open and ready to accept refugees and will consequently attract more refugees and illegal migrants to the country. ${ }^{84}$ Then, there is also considerable trepidation that more illegal immigrants will take advantage of the refugee status claim and the possibility of causing massive influx in the country. ${ }^{85}$ The ongoing problem of fake UNHCR identification papers and IMM13 pass only adds to the apprehension of bogus claims and the anticipated abuse of the refugee system if it were to be materialised. ${ }^{86}$ The last reason put forth by the government is that Malaysia is not in a position to tolerate the conciliation between its sovereignty, security, culture and policies to improving human rights protection ${ }^{87}$ despite being fully aware of the negative consequences of neglecting refugee children. ${ }^{88}$

83 Sara E. Davies, Legitimising Rejection: International Refugee Law in Southeast Asia (Martinuss Nijhoff Publisher, Leiden 2008) 6- 15.

${ }_{84}$ See SHM SNS RS, 'Pelarian Tidak Diiktiraf Tetapi Tetap Dibantu' Berita Harian ( Kuala Lumpur, 2 July 2007) 16; _, 'Syed Hamid: We Won't Recognise Refugees' New Straits Times (Kuala Lumpur, 9 March 2007) 8; and _Najib Disputes Refugee Report on Malaysia' New Straits Times (Kuala Lumpur, 21 June 2008) 2.

85 This is openly stated in the Malaysia National Security Council website. See National Security Council, 'Refugee' ( National Security Council, May 2009) < http://www.mkn. gov.my/v1/index.php/en/mkn-focus/focus_transnational-security> accessed 15 March 2010.

86 Bernama, 'UNHCR 'Aware and Concerned' About Fake Paper' Daily Express News (Kota Kinabalu, 5 March 2005) <http://www.dailyexpress.com.my/news. cfm?NewsID=32969> accessed 1 November 2010; _Fake IMM13 Refugee Document Seized' Daily Express News (Kota Kinabalu, 3 Oktober 2003) < http://www.dailyexpress. com.my/news.cfm?NewsID=22003> accessed 1 November 2010; and _Fake UN, Aceh ID Cards Sold to Illegals' The Star Online (Kuala Lumpur, 6 March 2008) $<\mathrm{http}: / /$ thestar.com.my/news/story.asp?file $=/ 2008 / 3 / 6 /$ nation $/ 20553830 \&$ sec $=$ nation $>$ accessed 24 September 2009. In 2007, six Myanmarese and two locals were arrested and charged with possession of forged documents. They are believed to be part of a syndicate which supply fake government documents including UNHCR cards to illegals. See Lourdes Charles, 'Forgery Ring Busted' The Star Online (Kuala Lumpur, 18 August 2007) <http:// thestar.com.my/news/story.asp?file $=/ 2007 / 8 / 18 /$ nation $/ 1862637 \&$ sec $=$ nation $>$ accessed 24 September 2009.

87 Haz Haz Zub Mo, 'Malaysia Not Planning to Join UN Convention on Refugees' New Straits Times (Kuala Lumpur, 17 April 2007) 8.

88 V. Vasudevan, 'Refugees 'a Perennial Problem for Malaysia', New Straits Times (Kuala Lumpur, 18 April 2007) 6. 


\section{The UNCRC: State Obligation towards Refugee Children}

Specific to refugee children, the UNCRC provides under Article 3 that the best interests of a child shall be a primary consideration in all actions concerning children. Public or private social welfare institutions, courts of law, administrative authorities and legislative bodies are all bound to follow the rule. Thus, the question whether a child seeking refuge in Malaysia can be deported or not should take into account a child's best interests. This also means that the treatment of refugee children should be based on the principle. Further, Article 22 provides that state parties are obliged to provide protection and assistance to a child who is seeking refugee status or who is considered a refugee so that they can enjoy the rights under the UNCRC and in other international instruments to which the said States are Parties. In its first mandatory report to the Committee for the Rights of the Child in 2006, ${ }^{89}$ Malaysia did not report on measures it has adopted to give effect to the provisions of the UNCRC, progress made in the states to enjoy the rights together with the factors that affect the endeavour to fulfil the obligation under the UNCRC. ${ }^{90}$ In the Concluding Observation ${ }^{91}$ the Committee on the Rights of the Child, they stated that the government should continue to prioritize budgetary allocations for the realization of children's rights to the maximum extent of available resources for social and health services, education and child protection and to allocate more resources for the implementation of special protection measures for vulnerable groups of children. ${ }^{92}$ In relation to refugee and asylum seekers, the Committee is particularly concerned that the implementation of the current provisions of the Immigration Act 1959/63 (Act 155) has resulted in detaining asylum-seeking and refugee children and their families at immigration detention centres, prosecuting them for immigration-related offences, and subsequently imprisoning and/or deporting them. Therefore, the Committee recommends that Malaysia should develop a legislative framework for the protection of asylum-seeking and refugee children in line with international standards. ${ }^{93}$

${ }^{89}$ The report was actually due in 1996 but it took 10 years for the authority to submit the report.

90 UNCRC, Article 44 (2)

91 UN Committee on the Rights of the Child (CRC), UN Committee on the Rights of the Child: Concluding Observations, Malaysia, 25 June 2007. CRC/C/MYS/CO/1.

92 Ibid., p. 5

93 Ibid., p. 12 


\section{Customary International Law}

Not being a contracting state to the CRSR is not an exhaustive excuse to escape responsibility under the International law. Non-contracting states are still bound to protect refugees to certain extent under the customary international laws. The first rule is the principle of nonrefoulement. It prevents state from rejecting, returning or removing refugees and asylum-seekers from their jurisdiction were this to expose them to a threat of persecution, or to a real risk of torture, cruel, inhuman or degrading treatment and punishment, or to a threat to life, physical integrity and freedom. ${ }^{94}$ The rule was applied and followed by states even before the adoption of the CRSR in 1951 and was codified in Article $33^{95}$ of the CRSR. Many commentators claim that the rule has become a customary international law which binds all states ${ }^{96}$ including Malaysia unless it can prove persistent objection. The second customary rule is the principle of the best interests of the child that demands all organs of state to make the best

${ }_{94}$ Lauterpacht, E., and Bethlehem, D., 'The Scope and Content of the Principle of NonRefoulement: Opinion' in Erika Feller, Volker Turk \& Frances Nicholson (eds), Refugee Protection in International Law' (Cambridge University Press, UK 2003) 31-54.

95 CRSR, Article 33:

1. No Contracting State shall expel or return ("refouler") a refugee in any manner whatsoever to the frontiers of territories where his life or freedom would be threatened on account of his race, religion, nationality, membership of a particular social group or political opinion.

2. The benefit of the present provision may not, however, be claimed by a refugee whom there are reasonable grounds for regarding as a dan- ger to the security of the country in which he is, or who, having been convicted by a final judgment of a particularly serious crime, constitutes a danger to the community of that country.

96 Lauterpacht, Bethlehem, Goodwin-Gill, Hailbronner, Mushkat, Stenberg and Allain, have espoused the idea that the principle has become a customary rule over time and the requirement of general and uniform state practice and the sense of obligation are inferred from various actions of states around the world. See Goodwin-Gill, G. S., and McAdam, J., The Refugee in International Law ( $3^{\text {rd }}$ Edition, Oxford University Press, Oxford 2007) 345-54; Lauterpacht, E., and Bethlehem, D., 'The Scope and Content of the Principle of Non-Refoulement: Opinion' in Erika Feller, Volker Turk \& Frances Nicholson (eds), Refugee Protection in International Law' (Cambridge University Press, UK 2003) 6470; Gunnel Stenberg, Non-Expulsion And Non- Refoulement (Iustus Forlag, Uppsala 1989); Roda Mushkat, 'Mandatory Repatriation Of Asylum Seekers: Is The Legal Norm Of Non-Refoulement 'Dead'?' (1995) 25 (1) HKLJ 42-51; Jean Allain, 'The Jus Cogens Nature of Non-Refoulement' (2001) 13 IJRL 538; and Seline Trevisanut, The Principle Of Non-Refoulement At Sea And The Effectiveness Of Asylum Protection' In Max Planck UNYB 12 (2008) 205-246. 
interests of the child as a paramount consideration before making a decision or taking any action. ${ }^{97}$ Nevertheless, it is not possible to make further discussion on Malaysia's obligation under customary international law due to limited space for the present article.

\section{Conclusion}

This paper has looked at the current laws in force to regulate immigrants particularly refugees. A close look at Malaysian laws confirms that the word refugee has never appeared or existed in any Malaysian legislation. In fact, there is no framework in place for the protection of refugee children. They have to rely on general laws to claim protection. Hence, it can be said that the existing legal framework is incapable of granting refugee children the protection guaranteed in international regime. Without express law refugee children are being put into the battle without arm and therefore their chance of survival is very slim. It is apparent that even though individuals are entitled to the protection of fundamental liberties under the Federal Constitution, the status and rights of immigrant in this country are usually referred to the framework of immigration law. This position has made the treatment of refugees to be confined within a narrow space and naturally defeating attempt to highlight their rights under the constitutional and human rights framework. The legal position of refugee children in Malaysia is very clear: they are considered illegal immigrant if they have no permission to stay or have no legal travel document. The identity papers issued by the UNHCR carries little weight and can be easily overruled by the authorities.

Reliance on Child Act 2001 to protect refugees and guarantee their rights also failed as the Act does not address refugee children in its provisions and is silent regarding any substantive rights of children even though it is was claimed that the Act was enacted in the spirit of Malaysia's obligation under the UNCRC. From the outset, Malaysia's failure to enact laws to regulate refugee matters is equivalent to refutation of refugee rights. Unless and until Malaysia realises and recognises the importance of conferring refugee status

97 Jean Zermatten, "The Best Interests of the Child Principle: Literal Analysis and Function" (2010) 18 Int'l. J. Child. Rts. 483- 499; and UNHCR, 'UNHCR Guideline on Formal Determination of the Best Interests of the Child' (UNHCR, 2006). 
particularly on refugee children their rights, refugees will continue to be in an indeterminate state. However the absence of express law does not necessarily mean that Malaysia cannot be held responsible under any law. From international law point of view, Malaysia is bound by the principles of customary international law and the Malaysian immigration law and practice are in violation of refugee children's rights protected under the principle of non- refoulement and the best interests of a child. Further treatment on this issue however is needed.

Preparing Malaysia to become a state that will accept, recognise and treat refugee according to international law requires concerted effort from various parties. NGOs and the authorities should work hand in hand to educate Malaysian people of all ages and races and help plant positive idea of refugees. The authorities and the society must be convinced with the importance of treating refugees as human rights holders and not as unwanted commodity. The next step is to gradually devise a specific framework to protect refugees. It is clear that building an ecosystem supportive of refugee protection is a long process but we have to start now or it will take longer.

\section{References}

Alexander, M.,'Refugee Status Determination Conducted by UNHCR' (1999) 11 (2) IJRL 251.

Allain, J., 'The Jus Cogens Nature of Non-Refoulement' (2001) 13 IJRL 538.

Amnesty International, Malaysia: Unlawful Killings, Custodial Deaths, Torture, Exploitation of Migrants and Cotinued Restrictions of Free Expression and Peaceful Assembly (Amnesty International, 2103) http://www.amnesty.org/en/ lib/asset/ASA28/003/2013/en/10af1c11-575f-41f4-a849e8a8c5f9c987/asa280032012en.pdf accessed 14 May 2014.

Arboleda, E., 'Refugee Definition in Africa and Latin America: The Lessons of Pragmatism' (1991) 3 (2) Int J Refugee Law 185207. 
Arshad, A H, "The Protection of Refugee Children in Malaysia: Wishful Thinking or Reality" (2004) INSAF (34: 4) 105.

Bahrin, T S., and Rachagan, S., 'The status of Displaced Filipinos in Sabah: Some policy Considerations and Their Long Term Implications' in Lim Joo-Jock Vani, S, Armed Separatism in Southeast Asia (Institute of Southeast Asian Studies, Singapore 1984)190.

Bernama 'Fake IMM13 Refugee Document Seized' Daily Express News (Kota Kinabalu, 3 Oktober 2003).

Bernama 'Fake UN, Aceh ID Cards Sold to Illegals' The Star Online (Kuala Lumpur, 6 March 2008) <http://thestar.com.my/news/ story.asp?file $=/ 2008 / 3 / 6 /$ nation $/ 20553830 \&$ sec $=$ nation $>$ accessed 24 September 2009.

Bernama, 'Najib: For Malaysia to decide and Not UNHCR' Daily Express (Sabah, 4 March 2005) <http://www.dailyexpress. com.my/news.cfm?NewsID $=33021>$ accessed 3 November 2010.

Bernama, 'UNHCR 'Aware and Concerned' About Fake Paper' Daily Express News (Kota Kinabalu, 5 March 2005) <http:// www.dailyexpress.com.my/news.cfm?NewsID=32969> accessed 1 November 2010.

Bernama, 'UNHCR 'Aware and Concerned' About Fake Paper' Daily Express News (Kota Kinabalu, 5 March 2005) <http:// www.dailyexpress.com.my/news.cfm?NewsID=32969> accessed 1 November 2010.

Bernama 'Syed Hamid: We Won't Recognise Refugees' New Straits Times (Kuala Lumpur, 9 March 2007) 8. < http://www. dailyexpress.com.my/news.cfm?NewsID $=22003>$ accessed 1 November 2010.

Bhabha, J., 'Independent Children, Inconsistent Adults: International Child Migration and the Legal Framework'. (2008) Innocenti Discussion Paper No. 08/3. UNICEF. 
Charles, L.'Forgery Ring Busted' The Star Online (Kuala Lumpur, 18 August 2007) <http://thestar.com.my/news/story.asp? file $=/ 2007 / 8 / 18 /$ nation $/ 1862637 \&$ sec $=$ nation $>$ accessed 24 September 2009.

Child Rights Coalition Malaysia, Status Report on Children's Rights in Malaysia December 2012 (CRCM 2012) http://www. psthechildren.org.my/media/upload/news/crc-malaysiareport-on-childrens-rights-2012-10.pdf accessed 22 August 2013.

Chin Human Rights Organisation, 'Seeking a Safe haven: Update on the Situation of the Chin in Malaysia' (Chin Human Rights Organisation, 2006) $<$ http://www.refugees.org/uploadedfiles/ CHRO\%200706Seeking_a_Safe_Haven.pdf

Chin Human Rights Organisation, Seeking a Safe haven: Living in Insecurity: Malaysia <http://www.refugees.org/uploadedfiles/ CHRO\%200706Seeking_a_Safe_Haven.pdf >accessed 13 January 2011 p. 4

Davies, S.E., Legitimising Rejection: International Refugee Law in Southeast Asia (Martinuss Nijhoff Publisher, Leiden 2008).

Farmer, A., "Refugee Responses, State-like Behavior, and Accountability for Human Rights Violations: A Case Study of Sexual Violence in Guinea's Refugee Camps" (2006) 9 Yale H.R. \& Dev. L. J. 44-103.

FIDH \& SUARAM, 'Undocumented Migrants and Refugees in Malaysia: Raids, Detention and Discrimination' (Report) (International Federation for Human Rights, 19 March 2008) http://www.fidh.org/IMG/pdf/MalaisieCONJ489eng.pdf accessed 15 November 2008.

Harding, A., Law, Government and the Constitution in Malaysia (Lexis Nexis, Kuala Lumpur 1996) 209.

Haz Haz Zub Mo, 'Malaysia Not Planning to Join UN Convention on Refugees' New Straits Times (Kuala Lumpur, 17 April 2007) 8 . 
HHS KHY HA, 'UNHCR Asked to Verify Status First Before Issuing Refugee Cards' Bernama (Malaysia, 19 February 2009).

Hugo,G. 'Postwar Refugee Migration in Southeast Asia: Patterns, Problems and Policy' in John R. Rogge (Ed), Refugee A Third World Dilemma (Rowman\& Littlefield Publisher, USA 1987) 242, 246.

Human Rights Watch, 'Aceh Under Martial Law: Problems Faced by Acehnese Refugees in Malaysia' (2004) Human Rights Watch Vol. 16. No. 5 (C).

Human Rights Watch, 'Aceh Under Martial Law: Problems Faced by Acehnese Refugees in Malaysia' (2004) Human Rights Watch Vol. 16. No. 5 (C).

Human Rights Watch, 'Living in Limbo Burmese Rohingyas in Malaysia' (Report) (Human Rights Watch, August 2000) $<$ http://www.hrw.org/legacy/reports/2000/malaysia/index. htm>accessed 23 June 2010.

Hussein Onn, 'Policy Towards Illegal Migrants' (1979) 2 Foreign Affairs Malaysia 216- 9; _, 'Malaysia Helps "Refugees” on Humanitarian Grounds' New Straits Times (Kuala Lumpur, 2 July 2007) 7.

Idris, A.,Malaysia and Forced Migration (2012) 20 (1) Intellectual Discourse 31-54.

Joseph Pairin Kitingan, 'Speech of Datuk Seri Panglima Joseph Pairin Kitingan, President of Parti Bersatu Sabah (PBS) (22 nd PBS Congres, 11 November 2007) in Hongkod Koisaan Penampang, Sabah http://www.pbs-sabah.org/pbs3/html/ Congress2007/ucapan_dasar_2007.html accessed 26 May 2009.

Kassim, A., 'Filipino Refugees in Sabah: State Responses, Public Stereotypes and the Dilemma Over Their Future' (2009) 47 Southeast Asian Studies 52. 
Kaur, A. 'Refugees and Refugee Policy in Malaysia' (2007) UNEAC Asia Papers (Special Issue Refugees and Refugee Policies in the Asia Pacific Region) 77, 79. <http://www.une.edu.au/ asiacentre/PDF/No18.pdf $>$ accessed 16 August 2009.

Kitingan, J. P., 'Speech of Datuk Seri Panglima Joseph Pairin Kitingan, President of Parti Bersatu Sabah (PBS) (22 nd PBS Congres, 11 November 2007) in Hongkod Koisaan Penampang, Sabah http://www.pbs-sabah.org/pbs3/html/ Congress2007/ucapan_dasar_2007.html accessed 26 May 2009.

Lauterpacht, E., and Bethlehem, D., 'The Scope and Content of the Principle of Non-Refoulement: Opinion' in Erika Feller, Volker Turk \& Frances Nicholson (eds), Refugee Protection in International Law' (Cambridge University Press, UK 2003) 31-54.

Lentini, E. J., 'The Definition of Refugee in International Law: Proposals For the Future' Ministry of Women, Family and Community Development, 'Implementation of the Convention on the Rights of the Child Malaysia's First Report' (2006).

Muntarbohrn, V.,The Status Of Refugees In Asia (Clarendon Press, London 1992).

Mushkat, R., 'Mandatory Repatriation of Asylum Seekers: Is The Legal Norm Of Non-Refoulement 'Dead'?' (1995) 25 (1) HKLJ 42-51.

Myanmar Ethnic Rohingyans Human Rights Organisation Malaysia (MERHROM), 'Rohingya Refugees' Dilemma Remains Unsolved' (MERHROM, 21 June 2007) http://merhrom. wordpress.com?2007/06/21/rohingya -refugees'-dilemma remains- unsolved

n.a, 'Beggars using refugee Status to Draw Sympathy' New Straits Times (Malaysia, 19 July 2003).

n.a. 'Najib Disputes Refugee Report on Malaysia' New Straits Times (Kuala Lumpur, 21 June 2008) 2. 
n.a. 'Rais: We Have No Intention to Codify Laws on Refugees, Asylum Seekers' New Straits Times (Kuala Lumpur, 25 October 2003) 3.

n.a. 'Syed Hamid: We Won't Recognise Refugees' New Straits Times (Kuala Lumpur, 9 March 2007) 8.

n.a. "Yuran Sekolah tahun depan di Mansuhkan" Utusan Malaysia. 8/10/2011. http://www.utusan.com.my/utusan/info.asp? y $=2011 \& \mathrm{dt}=1008 \& \mathrm{sec}=$ Muka_Hadapan $\&$ pg $=$ mh_03.htm Accessed 11 January 2012.

Nah, A. , "Refugee and Space in Urban Areas in Malaysia" (2010) 33 FMR 29- 29; Alica Nah and Tim Bunnel, "Ripples of Hope: Acehnese Refugees in Post- Tsunami Malaysia (2005) 26 (2) Singapore Journal of Tropical Geography 249- 256.

National Security Council, 'Refugee' ( National Security Council, May 2009) < http://www.mkn.gov.my/v1/index.php/en/mknfocus/focus_transnational-security $>$ accessed 15 March 2010.

NMR HK MIS, 'Police Detain Myanmar Refugee Found With Fake Identity Card' BERNAMA (Malaysia, 3 May 2009).

Olson. C., 13 $3^{\text {th }}$ of June 2007. "Malaysia: Undocumented Children in Sabah Vulnerable to Statelessness". Refugees International. www.refugeesinternational.org (Accessed 3 July 2012).

Paridah Abdul Samad and Darulsalam Abu Bakar, 'MalaysiaPhilippines Relations The Issue of Sabah' (1992) 32 (6) Asian Survey554- 567, 563.

Rachagan, S., 'Refugees and Illegal Immigrants: The Malaysian Experience with the Filipino and Vietnamese Refugees' in Rogge J R (ed) Refugees: A Third World Dilemma ( Rowman \& Littlefield, 1987).

Robinson, W. C.,Terms of Refuge: The Indochinese Exodus and The International Response (Zed Books Limited, London, 2000). 
Smythe,J.A., "I Came to United States and All I Got Was This Orange Jumpsuit" Age Determination Authority of Unaccompanied Alien Children and the Demand for Legislative Reform" (2004) Child. Legal Rts. J. 28.

Stenberg, G., Non-Expulsion And Non- Refoulement (Iustus Forlag, Uppsala 1989).

Sudarmo, R S 'Critical Issues in Forced Migration Studies and the Refugee Crisis in Southeast Asia (2007) UNEAC Asia Papers (Special Issue Refugees and Refugee Policies in the Asia Pacific Region) 13, $23<\mathrm{http}$ ://www.une.edu.au/asiacentre/ PDF/No14.pdf $>$ accessed 4 October 2010.

SHM SNS RS, 'Pelarian Tidak Diiktiraf Tetapi Tetap Dibantu' Berita Harian ( Kuala Lumpur, 2 July 2007) 16.

SUHAKAM, 'Report To The $14^{\text {th }}$ Annual Meeting Of The Asia Pacific Forum Of National Human Rights Institutions' (Amman, Jordan, 3-6 August 2009).

SUHAKAM, 2005 Annual Report (SUHAKAM, Kuala Lumpur 2006).

Suhrke, A., 'Indochinese Refugees: The Law and Politics of First Asylum'(1983) ANNALS AAPSS 102- 115, 102.

Sutter, V. O., The Indochinese Refugee Dilemma (Louisiana State University Press, London 1989).

SHM SNS RS, 'Pelarian Tidak Diiktiraf Tetapi Tetap Dibantu' Berita Harian ( Kuala Lumpur, 2 July 2007) 16.

The Malaysian Bar, Allowing Refugees and Asylum Seekers Access to lawful Employment is a Positive Step in the Right Direction (The Malaysian Bar, 2013) <http://www.malaysianbar.org. $\mathrm{my} /$ press_statement/press_release_allowing_refugees and_asylum_seekers_access_to_lawful_employment_is_a positive_step_in_the_right_direction.html $>$ accessed 30 September 2013. 
Thomas, N.,and Devaney, J., "Safeguarding Refugee and Asylumseeking Children" (2011) 20 Child Abuse Review 307- 310.

Trevisanut, S.,The Principle Of Non-Refoulement At Sea And The Effectiveness Of Asylum Protection' In Max Planck UNYB 12 (2008) 205-246.

UHNCR, 'UNHCR in Malaysia' at http://www.unher.org.my/cms/ basic-facts/unher-in-malaysia, accessed on 20 May 2013.

UN Committee on the Rights of the Child (CRC), UN Committee on the Rights of the Child: Concluding Observations, Malaysia, 25 June 2007. CRC/C/MYS/CO/1.

UNHCR, Country Operations Plan for 2007 Malaysia, available at http://www.unhcr.org/cgi-bin/texis/vtx/search?page=search $\&$ docid $=45221 \mathrm{ff} 62 \&$ query $=$ countryoperationsplanmalaysiaU NHCR, 'UNHCR Guideline on Formal Determination of the Best Interests of the Child' (UNHCR, 2006).

UHNCR, 'UNHCR in Malaysia' at http://www.unher.org.my/cms/ basic-facts/unhcr-in-malaysia, accessed on 20 May 2009.

UNHCR, Country Operations Plan for 2007 Malaysia, available at http://www.unhcr.org/cgibin/texis/vtx/ ch?page=search\&do $\mathrm{cid}=45221 \mathrm{ff} 62 \&$ query $=$ countryoperationsplanmalaysia

UNHCR Malaysia, 'Protection' (UNHCR Malaysia) < http://www. unhcr.org.my/What_We_Do-@-Protection.aspx $>$ accessed 5 September 2013.

UNHCR, Refugee Children: Guidelines on Protection and Care (1994)<http://www.refworld.org/docid/3ae6b3470.html> accessed 19 June 2014.

UNHCR Malaysia, Figures at a Glance (UNHCR Malaysia, 2014) $<$ http://www.unhcr.org.my/About_Us-@Figures_At_A_ Glance.aspx $>$ accessed 30 June 2014. 
US Committee for Refugees, The least risky solution: Malaysia's detention and deportation of Acehnese asylum seekers (US Committee for Refugees, Washington 1998)

US Committee for Refugees, The least risky solution: Malaysia's detention and deportation of Acehnese asylum seekers (US Committee for Refugees, Washington 1998); and Chin Human Rights Organisation, Seeking a Safe haven: Living in Insecurity: Malaysia <http:/www.refugees.org/uploadedfiles/ CHRO\%200706Seeking_a_Safe_Haven.pdf >accessed 13 January 2009 p. 4

V. Vasudevan, 'Refugees 'a Perennial Problem for Malaysia', New Straits Times (Kuala Lumpur, 18 April 2007) 6.

Wain, B., The Refused: The Agony of the Indochinese Refugees (Simon and Schuster, New York, 1982).

Young, W. A., 'The Protection of Refugee Women and Children Litmus Test for International Regime Success' (2002) 3 Geo. J. Int'1 Aff. 37- 44.

Zermatten, J.,"The Best Interests of the Child Principle: Literal Analysis and Function" (2010) 18 Int'l. J. Child. Rts. 483499. 